\title{
Uterine contractility in nonpregnant mares
}

\author{
T. Katila \\ University of Helsinki, Department of Clinical Veterinary Sciences, Saari Unit, Mäntsälä, Finland
}

\begin{abstract}
Summary
Uterine contractility has been studied by intrauterine pressure transducers - balloons or catheter tip pressure transducers - electromyography (EMG), transrectal ultrasound, and recently, by scintigraphy. Maximal uterine contractility was seen in ultrasonography during the late luteal phase (days 13 to 14), at the time of the expected luteolysis. Also in EMG, frequent spikes of short duration alternating with short periods of inactivity were reported during luteolysis. Total electrical activity was higher in dioestrus than in oestrus. Oestrus was characterised by shorter spikes of higher intensity separated by longer periods of inactivity as compared to dioestrus. Intrauterine infusion of bacteria increased myometrial electrical activity for 5 hours in all mares and for 18 hours in healthy mares resistant to uterine infections. Resistant mares exhibited greater uterine activity 10 to $20 \mathrm{~h}$ after inoculation than mares susceptible to uterine infections. Insemination (Al) caused spikes of higher amplitude and more frequent active phases for 2 to 7 hours as recorded by EMG. Scintigraphy showed how Al induced uterine contractions which were most frequent during the first 10 to $30 \mathrm{~min}$. Rectal palpation caused a transient increase in myometrial activity. Oxytocin increased myometrial activity at all stages of the cycle and prostaglandin $F_{2 \alpha}$ and its synthetic antagonists in cycling and steroidtreated mares. $\alpha 2$-agonists, detomidine, xylazine, and romifidine increased intrauterine pressure and electrical activity. Propantheline and acepromazine suppressed myometrial activity.
\end{abstract}

Keywords: $\quad$ Horse, myometrium, contraction, oestrous cycle, breeding

\section{Uterus-Kontraktilität bei nichttragenden Stuten}

Die uterine Kontraktilität wurde untersucht durch intrauterine Drucksensoren - Ballons oder Drucktransduktoren an einer Katheterspitze Elektromyographie (EMG), transrektal applizierter Ultrasonographie und - ganz aktuell - mit Hilfe der Szintigraphie. Maximale uterine Kontraktilität bei der zyklischen Stute wurde während der späten Lutealphase (Tag 13 bis 14) zur Zeit der zu erwartenden Luteolyse gemessen. Auch in der EMG wurden frequente Ausschläge kurzer Dauer abwechselnd mit kurzen Inaktivitätsphasen zur Zeit der Luteolyse beobachtet. Die elektrische Gesamtaktivität war höher im Diöstrus im Vergleich zum Östrus. Die Östrusphase war im Vergleich zum Interöstrus durch kürzere Ausschläge stärkerer Intensität getrennt durch längere Inaktivitätsperioden charakterisiert.

Die intrauterine Infusion von Bakterienkulturen erhöhte die myometriale elektrische Aktivität für über 5 Stunden bei allen untersuchten Stuten und für über 18 Stunden bei gesunden Stuten mit ausgeprägter Resistenz gegenüber uteriner Infektion (resistant mares). Resistente Stuten entwickelten 10 bis 20 Stunden nach Bakterieninokulation eine stärkere uterine Aktivität als für uterine Infektionen empfängliche Stuten (susceptible mares). Instrumentelle Sameneinführung verursachte EMG-Ausschläge mit größerer Amplitude und häufigere aktive kontraktile Phasen für 2 bis 7 Stunden. Die Szintigraphie demonstrierte die besamungs-induzierte uterine Aktivität, die in den ersten 10 bis 30 Minuten nach Sameneinführung am stärksten war. Die Palpation per rectum verursachte einen vorübergehenden Anstieg der myometrialen Aktivität. Die Applikation von Oxytocin verstärkte die myometriale Aktivität in allen Zyklusphasen, sowie Prostaglandin F2 alpha und seine synthetischen Antagonisten bei zyklischen und steroid-behandelten Stuten. Alpha 2 Agonisten - Detomidin, Xylazin und Romifidin - verstärkten den intrauterinen Druck und die elektrische Aktivität. Propanthelin und Azepromazin unterdrückten die myometrische Aktivität.

Schlüsselwörter: Pferde, Myometrium, Kontraktion, Zyklus, Frucht

\section{Introduction}

The vital role of uterine contractions in semen transport has been known for decades. Later, the importance of uterine contractions in the removal of excessive semen, bacteria and inflammatory by-products has been recognised. It has been suggested that the ability to clear uterine contents after breeding determines if a mare is resistant or susceptible to uterine infections. From the clinical point of view, it is important to know the effect of different drugs on uterine contractility.

\section{Methods to measure myometrial activity}

Different methods have been used to study uterine contractility in mares: intrauterine pressure transducers (IUP), electromyography (EMG), transrectal ultrasound, and scintigraphy. IUP utilised first microballoons, but later electronic catheter-tipped pressure transducers were developed. The pressure transducers consist of a catheter with one or two ultraminiature pressure sensors coupled by a cable to a recorder and a computer. The total area under the pressure curve, maximum intrauterine pressure and average intrauterine pressure have been used to demonstrate uterine motility (Ko et al., 1989). However, IUP is sensitive to various environmental stimuli. Changes in posture, level of alertness and fear induce transient variations in the IUP (Csapo, 1970). Urination, snorting, whinnying, stretching and respiration increased uterine pressures in mares (Goddard et al., 1985). Because the mare's uterus is nestled in intestinal coils, factors that affect intestinal tract motility can have a mechanical effect 
on the uterus, thus making IUP-measurements less reliable (Jones et al., 1991).

EMG has been used to study uterine electrical activity in mares since 1979 (Taverne et al., 1979). Four pairs of electrodes are surgically implanted in the myometrium (body, tip, middle and base of a horn) under general anesthesia, which makes the technique unsuitable for routine use. EMG measures electrical changes in the membrane potential of the myometrium, and there is a close relationship between electrical and mechanical activity in uterine smooth muscle (Troedsson et al., 1993a). Neither the direction of contractions, nor the direction of movement of intraluminal fluids can be studied with this technique (Troedsson et al., 1995). Also this method is sensitive to environmental stimuli. Entry to the mare's stall, feeding, and the sound of human voices induced temporary but marked changes in myometrial activity (Taverne et al., 1979). It is necessary to have an objective method for interpretation of EMG data to perform statistical analyses. The following system has been used by Troedsson et al. (1993a). A burst is defined as activity consisting of at least 10 recorded peaks/min and separated from other bursts by at least $1 \mathrm{~min}$. Frequency is defined as the number of activity bursts/hour. Intensity is the number of spikes $/ \mathrm{min}$, coded from 0 (quiescence) to high (> 20 spikes/min). All registered electrical activity is classified as total uterine activity. The presence or absence of synchronous activity is expressed as the number of implantation sites that are active simultaneously and the number which are quiescent simultaneously (Troedsson et al., 1993a).

Transrectal ultrasonography allows the visualisation of uterine contractions both in nonpregnant and pregnant animals. Active abdominal viscera near the uterus can confound uterine examination, and, therefore, it has been recommended that the uterus is examined only, when the ventral limits of the uterus can be delineated above a full urinary bladder (Griffin and Ginther 1990). Another concern is the effect of rectal palpation itself, since it has been known to increase the electrical activity of the myometrium (Taverne et al., 1979).

Static scintigrams have been used to study uterine clearance in mares (Neuwirth et al., 1995). Dynamic scintigrams allow the visualisation of uterine contractions, their direction and the movement of the inseminate (Katila et al., 1998). The radioactive material infused into the uterus may cause uterine contractions, as well as the sedatives which are necessary to carry out scintigraphy in horses (Katila et al., 1998). It is obvious that none of the techniques presented above is fully reliable in distinguishing natural uterine contractions from the ones induced by the use of the method itself or by environmental stimuli.

\section{Effect of cyclicity, stage of the cycle and exogenous steroid hormones}

Using transrectal ultrasonography, seasonally anovulatory mares were examined during 20 days: one group without hormone supplementation and 3 other groups with different regimens of hormonal supplementation. The average activity scores were constantly higher in steroid-treated groups than in the controls. A group of mares which received oestradiol on days 0 to 9 and progesterone on days 10 to 20 showed significantly greater uterine activity on days 4 to 11 than the other groups. The daily administration of oestradiol alone to anoestrous mares resulted in a gradual increase in uterine activity over days 1 to 5 . Perhaps oestrogen, in the absence of progesterone, stimulates uterine contractions during the oestrous cycle (Cross and Ginther, 1987).

EMG patterns were variable in anoestrus, and during transition they were more similar to those in oestrus than in dioestrus (Jones et al., 1991). Using IUP measurements, there was no statistical difference in spontaneous uterine motility between oestrus and dioestrus (Ko et al., 1989). In EMG, oestrus was characterised by well defined, but short phases of activity with closely grouped high-amplitude spikes (or high intensity bursts) separated by long periods of complete inactivity. During dioestrus, more diffuse phases of activity with low-amplitude spikes were separated by variable periods of relative inactivity (Taverne et al., 1979; Troedsson et al., 1993a). In contrast, the total time of uterine activity was higher during dioestrus than during oestrus. This correlates well with the increased tone and tubularity that is characteristic of the equine uterus at dioestrus upon rectal palpation (Troedsson et al., 1993a). Synchronisation of uterine electrical activity at different sites of the uterus was more marked during oestrus than during dioestrus. This suggests a hormone dependent mechanism for the regulation of cell communication during oestrus (Troedsson et al., 1993a). Progesterone inhibits and oestrogen stimulates formation of gap junctions in the myometrium (Garfield et al., 1980). A wave of synchronised uterine activity is important for sperm transport and for the removal of excessive semen, bacteria and inflammatory by-products.

In transrectal ultrasonography, a postovulatory decrease in activity scores was observed between days 0 and 1 followed by a progressive increase between days 2 and 4 . Activity scores increased again between days 11 and 12 , being maximal during the late luteal phase (days 13 to 14), the time of onset of luteolysis. At the time of the lowest activity, days 0 to 1 , the concentrations of steroids are low. Perhaps critical levels of oestradiol or progesterone must be reached, or a critical oestradiol:progesterone ratio is necessary to stimulate uterine activity (Griffin and Ginther, 1990).

\section{Effect of oxytocin and prostaglandins}

Oxytocin (OT) increases uterine activity rapidly $(<1 \mathrm{~min}$ ) for 20 to 60 min (Table 1). The number of OT-binding sites was greatest during days 14 to 17 of the cycle. This may be due to the increasing concentration of oestradiol, which has a stimulatory effect on oestrogen and OT-binding sites and thus promotes increased PGF $_{2 \alpha}$ synthesis (Stull and Evans, 1986). The results of Troedsson et al. (1995) suggest that the mare myometrium has sufficient receptors to respond to a pharmacological dose of OT during both oestrus and 
dioestrus. Oestrogen priming does not seem to be necessary in the mare, since anoestrous and dioestrous mares responded to OT by increased uterine pressure (Goddard and Allen, 1985).

$\mathrm{PGE}_{2}, \mathrm{PGF}_{2 \alpha}$ and its synthetic analogues, cloprostenol and fluprostenol, stimulate uterine contractions (Table 1). Seasonally anovulatory mares failed to respond to $\mathrm{PGF}_{2 \alpha}$, whereas anovulatory mares treated with steroids showed a positive response. This indicates that the mare's uterus may require prior exposure to oestrogen, progesterone or both (Cross and Ginther, 1987). Prostaglandins have a longer effect than OT and could, therefore, be more effective in the treatment of mares with uterine clearance problems.

\section{The effect of $\alpha 2$-adrenoceptor agonists and antagonists}

$\alpha 2$-adrenoceptor agonists seem to stimulate uterine contractions both in oestrous and dioestrous mares, whereas the agonist, acepromazine, has an inhibitory effect in dioestrous mares (Table 2). None of the studies has compared the effect during different stages of the cycle. It could be expected that the effect would be more pronounced during oestrus, since oestrogen increases the number of $\alpha 2$ adrenoceptors (Hoffman et al., 1981). The effect on uterine contractility is shorter than the duration of sedation which is approx. one hour. Receptors in the myometrium may require higher systemic levels than other target tissues (Schatzmann et al., 1994).

Xylazin priming of OT increased the length of the first IUP wave and prolonged the contraction time in mares with delayed uterine clearance. When mares with delayed uterine clearance were injected with acepromazine followed by an OT-injection of $10 \mathrm{IU}$, the number of IUP waves decreased (LeBlanc et al., 1998). These kind of differences can be important in clinical situations. When uterine contractions are desired, e.g. after breeding, during embryo recovery and particularly in mares with delayed uterine clearance, $\alpha 2-$ agonists could be the drug of choice.

Tab. 1: The effect of oxytocin and prostaglandins on uterine contractions.

Der Einfluß von Oxytocin und Prostaglandinen auf uterine Kontraktionen.

\begin{tabular}{|l|l|l|l|l|l|l|l|}
\hline Author & Method & Drug & Dose & Onset & Duration & $\begin{array}{l}\text { Number } \\
\text { of mares }\end{array}$ & Remarks \\
\hline \hline
\end{tabular}

Oxytocin (OT), IU = international units, EMG = electromyography, IUP = intrauterine pressure

\begin{tabular}{|c|c|c|c|c|c|c|c|}
\hline LeBlanc et al. 1994 & scintigraphy & OT & $20 \mathrm{IU}$ & $8 \mathrm{~min}$ & & 17 & $90 \%$ clearance in $30 \mathrm{~min}$ \\
\hline Cadario et al. 1995 & scintigraphy & OT & $20 \mathrm{IU}$ & $5 \min$ & & 4 & $85 \%$ clearance in 30 min \\
\hline Jones et al. 1991 & EMG & OT & $5 \mathrm{IU}$ & $20-50 \mathrm{sec}$ & & 2 & more pronounced effect in oestrus \\
\hline $\begin{array}{l}\text { Troedsson } \\
\text { et al. } 1995\end{array}$ & EMG & OT & 2010 & & $1 \mathrm{~h}$ & 5 & frequency higher in oestrus \\
\hline Ko et al. 1989 & IUP & OT & $40 \mathrm{IU}$ & $2-3 \mathrm{sec}$ & $0 \mathrm{~min}$ & 3 & stage of cycle made no difference \\
\hline $\begin{array}{l}\text { Goddard and } \\
\text { Allen } 1985\end{array}$ & IUP & OT & $2 \mathbb{I U}$ & $1 \min$ & $20 \mathrm{~min}$ & 5 & \\
\hline $\begin{array}{l}\text { Goddard and } \\
\text { Allen } 1985\end{array}$ & IUP & $\begin{array}{c}\text { PGF }_{2 \alpha} \\
\text { cloprostenol }\end{array}$ & $\begin{array}{c}2.5 \mathrm{mg} \\
75 \mu \mathrm{g}\end{array}$ & $\begin{array}{l}10 \mathrm{~min} \\
10 \mathrm{~min}\end{array}$ & $\begin{array}{l}40 \mathrm{~min} \\
60 \mathrm{~min}\end{array}$ & $\begin{array}{l}5 \\
5\end{array}$ & \\
\hline $\begin{array}{l}\text { Cross and } \\
\text { Ginther } 1987\end{array}$ & $\begin{array}{l}\text { ultrasono- } \\
\text { graphy }\end{array}$ & $\mathrm{PGF}_{2 \alpha}$ & $3 \mathrm{mg}$ & $30 \min$ & $2 \mathrm{~h}$ & 4/group & no effect in anovulatory mares \\
\hline Cross et al. 1991 & EMG & $\mathrm{PGF}_{2 \alpha}$ & $10 \mathrm{mg}$ & $8 \min$ & & 2 & during luteal phase \\
\hline $\begin{array}{l}\text { Troedsson } \\
\text { et al. } 1995\end{array}$ & EMG & $\begin{array}{l}\mathrm{PGF}_{2 \alpha} \\
\mathrm{PGE}_{2}\end{array}$ & $\begin{array}{l}10 \mathrm{mg} \\
10 \mathrm{mg}\end{array}$ & & $\begin{array}{l}5 \mathrm{~h} \\
3 \mathrm{~h}\end{array}$ & $\begin{array}{l}5 \\
5\end{array}$ & frequency higher in oestrus \\
\hline Jones et al. 1991 & EMG & cloprostenol & $125 \mu \mathrm{g}$ & $8-10 \mathrm{~min}$ & $3 h$ & 2 & more pronounced effect in oestrus \\
\hline
\end{tabular}




\section{The effect of other treatments}

\section{Clenbuterol}

Clenbuterol is known to be an effective uterine relaxant. An intravenous dose of $3 \mathrm{mg}$ slightly reduced amplitude and total EMG activity, but all changes were minimal and not significant (Jones et al., 1991).

\section{Propantheline}

Propantheline bromide inhibits peristaltic movements of the intestines and is used commonly for this purpose. An intravenous dose of $100 \mathrm{mg}$ decreased total EMG activity within 1 to $2 \mathrm{~min}$, whereas the increase in amplitude was not consistent in all animals. The EMG response suggests uterine relaxation (Jones et al., 1991).

Transrectal palpation and vaginoscopy

Rectal examination caused a brief burst of 2 to $5 \mathrm{~min}$ in EMG activity when carried out during a period of relative inactivity. When performed during an active period, the density of spikes increased (Jones et al., 1991). In the study of Taverne et al. (1979), myometrial electrical activity had already begun, when the palpator had entered the mare's stall and prepared for the examination. Activity continued during palpation but lasted only a few minutes after it was completed, and no significant changes in the pattern of
EMG occurred afterwards. Similar EMG changes were caused by the insertion of a speculum into the vagina (Taverne et al., 1979).

Effect of mating, artificial insemination (Al) and intrauterine bacterial inoculation

During mating and for up to 8 min after, the density of the EMG spikes increased from an average of 17 bursts/min prior to breeding to 40 bursts/min post breeding, then quickly declined to prebreeding levels (Jones et al., 1991). At the time of Al, myometrial activity was similar to that observed during rectal palpation. After Al the activity in-creased markedly, with spikes of higher amplitude and more frequent active phases persisting for 2 to $7 \mathrm{~h}$ (Taverne et al., 1979).

After Al with radiolabelled (Technetium-99m) sperm, strong and frequent uterine contractions were seen in dynamic scintigrams. The frequency of contractions showed a lot of variation between the mares. One mare had only 5 contractions/30 min, whereas the other two mares exhibited 35 and 65 contractions within the first $30 \mathrm{~min}$. The contractions pushed sperm continuously back and forth between the body and the tips of the horns during the first $20 \mathrm{~min}$. Often, there were from 4 to 7 circular movements of sperm in the uterine body or in the most ventral parts of uterine horns which was followed by a rapid influx into the tip of the horn and subsequent return to the body. Localised horn

Tab. 2: The effect of $\alpha 2$-agonists and -antagonists on uterine contractions.

Der Einfluß von $\alpha 2$-Agonisten und -Antagonisten auf uterine Kontraktionen.

\begin{tabular}{|c|c|c|c|c|c|c|}
\hline Author & Method & Dose & Onset & Duration & $\begin{array}{l}\text { Number } \\
\text { of mares }\end{array}$ & Remarks \\
\hline \multicolumn{7}{|l|}{ Xylazine } \\
\hline Schatzmann et al. 1994 & IUP & $0.1 \mathrm{mg} / \mathrm{kg}$ & $4 \min$ & $20 \mathrm{~min}$ & 4 & $71 \%$ increase \\
\hline LeBlanc et al. 1998 & IUP & $0.5 \mathrm{mg} / \mathrm{kg}$ & & $11 \mathrm{~min}$ & 8 & during oestrus increase \\
\hline Gibbs \& Troedsson 1995 & EMG & $0.5 \mathrm{mg} / \mathrm{kg}$ & & $30 \mathrm{~min}$ & 5 & during dioestrus $24 \%$ increase \\
\hline \multicolumn{7}{|l|}{ Detomidine } \\
\hline Gibbs \& Troedsson 1995 & EMG & $0.015 \mathrm{mg} / \mathrm{kg}$ & & $60 \mathrm{~min}$ & 5 & during dioestrus $47 \%$ increase \\
\hline Schatzmann et al. 1994 & IUP & $0.04 \mathrm{mg} / \mathrm{kg}$ & $6 \mathrm{~min}$ & $30 \mathrm{~min}$ & 4 & $45 \%$ increase \\
\hline \multicolumn{7}{|l|}{ Romifidine } \\
\hline Schatzmann et al. 1994 & IUP & $0.08 \mathrm{mg} / \mathrm{kg}$ & $5 \mathrm{~min}$ & $18 \mathrm{~min}$ & 4 & $37 \%$ increase \\
\hline \multicolumn{7}{|l|}{ Acepromazine } \\
\hline Gibbs \& Troedsson 1995 & EMG & $0.05 \mathrm{mg} / \mathrm{kg}$ & & $90 \mathrm{~min}$ & 5 & during dioestrus $18 \%$ decrease \\
\hline LeBlanc et al. 1998 & IUP & $0.05 \mathrm{mg} / \mathrm{kg}$ & & no effect & 8 & during oestrus \\
\hline
\end{tabular}


contractions seemed to close the uterine lumen for short periods of time. The elimination of sperm was rapid: $2.5 \mathrm{~h}$ after Al the majority of sperm had left the uterus and by $4.5 \mathrm{~h}$ most sperm had been eliminated from the mare (Katila et al., 1998).

After an intrauterine infusion of streptococci on the $3^{\text {rd }}$ day of oestrus, an increase in myometrial activity was seen in all mares for $5 \mathrm{~h}$ and in resistant mares for $18 \mathrm{~h}$. Resistant mares demonstrated greater myometrial activity than did mares susceptible to endometritis. Statistically significant differences were observed in frequency as well as duration and intensity of the uterine activity. Differences were most marked between 10 and $20 \mathrm{~h}$ after the bacterial inoculation (Troedsson et al., 1993b).

\section{Literature}

Cadario, Maria, Thatcher, Marie-Joelle D. and LeBlanc, Michelle M. (1995): Relationship between prostaglandin and uterine clearance of radiocolloid in the mare. Biol. Reprod. Mono 1, 495-500.

Cross, D.T. and Ginther, O. J. (1987): The effect of estrogen, progesterone and prostaglandin $\mathrm{F}_{2 \alpha}$ on uterine contractions in seasonally anovulatory mares. Dom. Anim. Endocr. 4, 271-278.

Csapo A. (1970): The diagnostic significance of the intrauterine pressure. Obstet. Gynecol. 25, 403-435.

Garfield, R.E., Kannan, M.S. and Daniel, E.E. (1980): Gap junction formation in myometrium: control by estrogens, progesterone, and prostaglandins. Am. J. Physiol. 238, C81-C89.

Gibbs, H.M. and Troedsson, M.H.T. (1995): Effect of acepromazine, detomidine, and xylazine on myometrial activity in the mare. Biol. Reprod. Mono 1, 489-493.

Goddard, P.J., Allen, W.E. and Gerring, E.L. (1985): Genital tract pressures in mares. I. Normal pressures and the effect of physiological events. Theriogenology 23, 815-827.

Griffin, P.G. and Ginther, O.J. (1990): Uterine contractile activity in mares during the estrous cycle and early pregnancy. Theriogenology $34,47-56$.

Hoffman, B.B., Lavin, T.N., Lefkowitz, J. and Ruffolo Jr, R. (1981): Alpha andrenergic receptor subtypes in rabbit uterus: Mediation of myometrial contraction and regulation by estrogens. J. Pharmacol. Exp. Ther. 219, 290-295.

Jones, D.M., Fielden, E.D. and Carr, D.H. (1991): Some physiological and pharmacological factors affecting uterine motility as measured by electromyography in the mare. J. Reprod. Fert., Suppl. 44, 357-368.

Katila, Terttu, Sankari, Satu, and Mäkelä, O. (1998): Transport of spermatozoa in the mare's genital tract studied by a scintigraphic method. Proc. Ann. Meet. Soc. Theriog., Baltimore, Maryland, 173-174.
Ko, J.H.C., Lock, T.F., Davis, J.L. and Smith, R.P. (1989): Spontaneous and oxytocin-induced uterine motility in cyclic and postpartum mares. Theriogenology 32, 643-651.

LeBlanc, Michelle, Neuwirth, L., Mauragis, D., Klapstein, E. and Tran, T. (1994): Oxytocin enhances clearance of radiocolloid from the uterine lumen of reproductively normal mares and mares susceptible to endometritis. Equine vet. J. 26, 279-282.

LeBlanc, Michelle M., De Lille, Alexandra, Cadario, Maria E. and Tran, T.Q. (1998): Tranquilization affects intrauterine pressure in mares administered oxytocin. Proc. Am. Ass. Eq. Pract. 44, 54-55.

Neuwirth, L., LeBlanc, Michelle, Mauragis, F., Klapstein, E. and Tran, T. (1995): Scintigraphic measurement of uterine clearance in mares. Vet. Radiol. \& Ultrasound 36, 64-68.

Schatzmann, U., Josseck, H., Stauffer, J.-L. and Goossens, L. (1994): Effects of $\alpha 2$-agonists on intrauterine pressure and sedation in horses: Comparison between detomidine, romifidine and xylazine. J. Vet. Med A 41, 523-529.

Stull, C.L. and Evans, J.W. (1986): Oxytocin binding in the uterus of the cycling mare. Eq. Vet. Sci. 6, 114-119.

Taverne, M.A.M., van der Weyden, G.C., Fontijne, P., Dieleman, S.J., Pashen, R.L. and Allen, W.R. (1979): In-vivo myometrial electrical activity in the cyclic mare. J. Reprod. Fert. 56, 521-532.

Troedsson, M.H.T., Wiström, A.O.G., Liu, I.K.M., Ing, M., Pascoe, J. and Thurmond, $M$. (1993): Registration of myometrial activity using multiple site electromyography in cyclic mares. J. Reprod. Fert. 99, 299-306a

Troedsson, M.H.T., Liu, I.K.M., Ing, M., Pascoe, J. and Thurmond, M. (1993): Multiple site electromyography recordings of uterine activity following an intrauterine bacterial challenge in mares susceptible and resistant to chronic uterine infection. J. Reprod. Fert. 99, 307-313b.

Troedsson, M.H.T., Liu, I.K.M., Ing, M. and Pascoe, J. (1995): Smooth muscle electrical activity in the oviduct, and the effect of oxytocin, prostaglandin F2a, and prostaglandin E2 on the myometrium and the oviduct of the cycling mare. Biol. Reprod. Mono 1, $475-488$.

\section{Prof Terttu Katila}

University of Helsinki

Saari Unit

Pohjoinen Pikatie 800

FIN-04920 Saarentaus

$\operatorname{tax}+358-19-6851181$

tel +358-19-5295303

terttu.katila@he/sinki.fi 